\title{
Karakteristik Pasien Penyakit Jantung Rematik yang Dirawat Inap di RSUP Dr. M. Djamil Padang
}

\author{
Marhamah Hasnul ${ }^{1}$, Najirman², Yanwirasti $^{3}$
}

\begin{abstract}
Abstrak
Penyakit jantung rematik (PJR) adalah penyakit jantung sebagai akibat adanya gejala sisa (sekuele) dari demam rematik (DR) yang ditandai dengan terjadinya cacat katup jantung. Tujuan penelitian ini adalah melihat karakteristik pasien penyakit jantung rematik.yang dirawat. Metode yang digunakan adalah deskriptif observasional dengan desain cross sectional study dan pendekatan retrospektif untuk menilai karakteristik pasien PJR di RSUP Dr. M. Djamil Padang dari Januari 2009 - Desember 2012. Populasi dan sampel sebanyak 54 sampel. Hasil penelitian menunjukkan distribusi pasien terbanyak pada kelompok umur $11-20$ tahun (50\%), perempuan $(57,41 \%)$, tingkat pendidikan SD/sederajat dan SLTP/sederajat masing-masing 25,93\%, pelajar/mahasiswa (53,70\%), dan berasal dari daerah rural (70,37\%). Sebagian besar pasien mengeluhkan keluhan utama sesak napas (62,96\%). Hasil pemeriksaan elektrokardiografi memperlihatkan LVH sebesar 35,19\% dan AF sebesar 27,78\%. Berdasarkan pemeriksaan foto toraks umumnya pasien telah mengalami kardiomegali (92,59\%). Berdasarkan pemeriksaan ekokardiografi yang paling banyak ditemukan adalah kelainan katup regurgitasi mitral $(30,40 \%)$, derajat kerusakan katup berat $(36,80 \%)$, dan fraksi ejeksi normal (72,97\%). Pada penelitian ini dapat disimpulkan bahwa terdapat variasi karakteristik dari penderita PJR yang ada di RSUP Dr. M. Djamil Padang.
\end{abstract}

Kata kunci: penyakit jantung rematik, karakteristik

\begin{abstract}
Rheumatic heart disease is a cardiovascular disease caused by delayed sequele of rheumatic fever characterized by heart valve damage. The objective of this study was to observe the characteristics of RHD patients. This study is a descriptive observasional with cross-sectional study design and the retrospective by observing the characteristics of RHD patients in RSUP Dr. M. Djamil Padang from Januari 2009 - December 2012. The population and sample of this study was 54 patients. The result of this study showed that majority of the patients at the age group 11-20 years (50\%), female (57.41\%), elementary education degree/equal and junior high/equal of each $25.93 \%$, students/university students (53.70\%), and come from rural areas (70.37\%). Most patients complained experienced breathlessness (62.96\%). The result of electrocardiography showed LVH is the the highest (35.19\%) and AF $27.78 \%$. Based on chest X-ray examination majority of the patients showed a cardiomegaly (92.59\%). Based on echocardiography examination, the most heart valve damage is mitral regurgitation (30.40\%), the severity is severe (36.80\%), and the fraction ejection is in normal limit (72.97\%). The conclusion of this research, there are variation in the characteristics of RHD patients in RSUP Dr. M. Djamil Padang.
\end{abstract}

Keywords: rheumatic heart disease, characteristics

Affiliasi penulis: 1. Pendidikan Dokter FK UNAND (Fakultas Kedokteran Universitas Andalas Padang), 2. Bagian Rematologi IImu Penyakit Dalam FK UNAND/RSUP Dr. M. Djamil Padang, 3. Bagian Anatomi FK UNAND.

Korespondensi: Marhamah Hasnul

E-mail: marhamah_hasnul@yahoo.com, No. Telp: 085364590100

\section{PENDAHULUAN}

Demam Rematik (DR) dan Penyakit Jantung Rematik (PJR) masih menjadi penyebab penyakit kardiovaskular yang signifikan di dunia. ${ }^{`}$ Kejadian DR akut dan PJR di negara industri menurun selama lima dekade terakhir, namun PJR ini masih tetap menjadi 
masalah di negara industri dan negara berkembang hingga permulaan abad ke-21 dengan efek yang buruk mengenai anak-anak dan dewasa muda pada usia produktif. ${ }^{1}$ Dalam laporan World Health Organization (WHO) Expert Consultation Geneva pada tahun 2001, pada tahun 1994 diperkirakan 12 juta penduduk dunia menderita DR dan PJR, dan paling tidak 3 juta diantaranya menderita penyakit jantung kongestif. Pada tahun 2000, dilaporkan angka kematian akibat PJR bervariasi di setiap negara, mulai dari 1,8 per 100.000 penduduk di Amerika hingga 7,6 per 100.000 penduduk di Asia Tenggara. ${ }^{1}$ Prevalensi DR di Indonesia belum diketahui secara pasti. Dalam beberapa penelitian yang pernah dilakukan menunjukkan bahwa prevalensi PJR berkisar antara 0,3 - 0,8 per 1.000 anak sekolah. ${ }^{2}$ Dengan demikian, dapat diperkirakan bahwa prevalensi DR di Indonesia lebih tinggi dari angka tersebut, mengingat PJR merupakan akibat dari DR. Berdasarkan laporan Leman, menurut pola etiologi penyakit jantung yang dirawat di Bagian IImu Penyakit Dalam RSUP Dr. M. Djamil Padang tahun 1973-1977 didapatkan 31,4\% pasien DR/PJR pada usia 10-40 tahun, dengan mortalitas $12,4 \%{ }^{3}$

Kejadian PJR di negara maju sangat kontras dibandingkan dengan kejadian di negara berkembang. $\mathrm{Hal}$ ini dihubungkan dengan beberapa faktor, termasuk faktor sosioekonomi dan lingkungan yang secara tidak langsung berperan dalam kejadian DR dan PJR. ${ }^{1}$ Faktor-faktor yang terkait adalah keterbatasan pelayanan kesehatan yang berkualitas, kurangnya tenaga ahli yang menangani, status ekonomi, kepadatan penduduk, status nutrisi, keadaan rumah, keadaan lingkungan dan rendahnya kesadaran terhadap penyakit, yang dapat berdampak pada munculnya penyakit DR/PJR di masyarakat di negara berkembang. ${ }^{1}$

Infeksi streptococcus $\beta$ Hemolitikus Grup A (SGA) masih belum dapat dieradikasi yang berdampak pada kejadian DR dan PJR. ${ }^{4}$ Penyakit jantung rematik merupakan penyebab kecacatan pada jantung yang terbanyak. Kecacatan pada katup jantung tidak dapat terlihat secara kasat mata seperti cacat fisik lainnya, tetapi menyebabkan gangguan kardiovaskuler mulai dari bentuk ringan sampai berat sehingga mengurangi produktivitas dan kualitas hidup. ${ }^{4}$
Data mengenai kejadian PJR di Indonesia tidak tersedia secara lengkap dan akurat. Data yang ada kebanyakan di-sampaikan dalam bentuk data di rumah sakit atau unit kesehatan, dan sukar dicari data secara nasional. Umumnya data terakhir yang tercatat berasal dari tahun 1990an. Data terbaru untuk wilayah Sumatera Barat sendiri masih belum tersedia. Hal ini membuat penulis merasa tertarik untuk melakukan penelitian mengenai PJR di RSUP Dr. M. Djamil Padang. Diharapkan dengan penelitian ini akan diketahui karakteristik dari PJR yang ada di RSUP Dr. M. Djamil Padang dan dapat bermanfaat dalam peningkatan penanganan, pencegahan serta eradikasi dari PJR untuk wilayah Sumatera Barat pada khususnya dan Indonesia pada umumnya.

\section{METODE}

Penelitian ini merupakan penelitian deskriptif observasional dengan desain cross sectional study dan pendekatan retrospektif untuk menilai karakteristik pasien PJR. Penelitian ini dilakukan melalui pengambilan data sekunder di bagian rekam medik RSUP Dr. M. Djamil Padang. Penelitian ini dilakukan selama 1 tahun. Populasi dalam penelitian ini adalah seluruh data rekam medik pasien yang didiagnosa menderita PJR di RSUP Dr. M. Djamil Padang. Sampel dalam penelitian ini diambil dari data rekam medik dengan menggunakan teknik total sampling. Sampel adalah bagian dari populasi yang memenuhi kriteria inklusi : (1) Data rekam medik pasien yang telah didiagnosa menderita PJR oleh dokter dan dirawat inap di RSUP Dr. M. Djamil Padang dari Januari 2009 Desember 2012, (2) Data rekam medik pasien PJR yang dirawat inap di RSUP Dr. M. Djamil Padang dari Januari 2009 - Desember 2012 yang lengkap dan sesuai dengan variabel penelitian.

\section{HASIL}

Penelitian ini mencakup 54 sampel dengan distribusi pasien PJR berdasarkan sosiodemografi bervariasi (tabel 1.). Distribusi pasien PJR berdasarkan umur yang tertinggi adalah pada kelompok umur 11-20 tahun, yaitu sebanyak 27 sampel (50\%). Dari 54 sampel terdapat 31 orang $(57,41 \%)$ berjenis kelamin perempuan dan 23 orang (42,59\%) berjenis kelamin 
laki-laki. Berdasarkan tingkat pendidikan yang tertinggi adalah SD/sederajat dan SLTP/sederajat masingmasing 14 orang (25,93\%). Berdasarkan pekerjaan yang tertinggi adalah pelajar/mahasiswa, yaitu 29 orang (53,70\%). Sebagian besar sampel berasal dari daerah rural, yaitu 38 orang $(70,37 \%)$ dan dari daerah urban sebanyak 16 orang $(29,63 \%)$.

Tabel 1. Distribusi pasien PJR berdasarkan sosio demografi

\begin{tabular}{|c|c|c|}
\hline Sosiodemografi & $\mathbf{n}$ & $\%$ \\
\hline \multicolumn{3}{|l|}{ Umur } \\
\hline 0-10 tahun & 4 & 7,41 \\
\hline $11-20$ tahun & 27 & 50 \\
\hline 21 - 30 tahun & 12 & 22,22 \\
\hline $31-40$ tahun & 5 & 9,26 \\
\hline $41-50$ tahun & 2 & 3,70 \\
\hline $51-60$ tahun & 3 & 5,56 \\
\hline$>60$ tahun & 1 & 1,85 \\
\hline Jumlah & 54 & 100 \\
\hline \multicolumn{3}{|l|}{ Jenis Kelamin } \\
\hline Perempuan & 31 & 57,41 \\
\hline Laki-laki & 23 & 42,59 \\
\hline Jumlah & 54 & 100 \\
\hline \multicolumn{3}{|l|}{ Pendidikan } \\
\hline Belum/tidak sekolah & 12 & 22,22 \\
\hline SD/sederajat & 14 & 25,93 \\
\hline SLTP/sederajat & 14 & 25,93 \\
\hline SLTA/sederajat & 12 & 22,22 \\
\hline Akademi/PT & 2 & 3,70 \\
\hline Jumlah & 54 & 100 \\
\hline \multicolumn{3}{|l|}{ Pekerjaan } \\
\hline Pelajar/Mahasiswa & 29 & 53,70 \\
\hline PNS/TNI/Pensiunan & 3 & 5,56 \\
\hline Pegawai swasta & 3 & 5,56 \\
\hline Ibu Rumah Tangga & 6 & 11,11 \\
\hline Petani/Nelayan & 2 & 3,70 \\
\hline Tidak bekerja & 11 & 20,37 \\
\hline Jumlah & 54 & 100 \\
\hline \multicolumn{3}{|l|}{ Daerah asal } \\
\hline Rural & 38 & 70,37 \\
\hline Urban & 16 & 29,63 \\
\hline Jumlah & 54 & 100 \\
\hline
\end{tabular}

Keluhan utama pasien PJR yang paling sering muncul adalah sesak napas yang dikeluhkan oleh 34 orang(Tabel 2.).
Tabel 2. Distribusi pasien PJR berdasarkan keluhan utama

\begin{tabular}{lcc}
\hline \multicolumn{1}{c}{ Keluhan Utama } & $\mathbf{n}$ & $\%$ \\
\hline Keluhan Jantung & 34 & 62,96 \\
Sesak napas & 6 & 11,11 \\
Dada berdebar & 3 & 5,56 \\
Sesak napas dan nyeri dada & 2 & 3,70 \\
Nyeri dada & 1 & 1,85 \\
Sesak napas dan mudah lelah & 1 & 1,85 \\
Sesak napas, korea, dan nyeri sendi & 1 & 1,85 \\
Sesak napas disertai batuk & & \\
& & \\
Keluhan lain & 2 & 3,70 \\
Lemah anggota gerak & 2 & 3,70 \\
Perut membesar & 1 & 1,85 \\
Penurunan kesadaran & 1 & 1,85 \\
Nyeri pinggang & 54 & 100 \\
\hline \multicolumn{1}{c}{ Jumlah } &
\end{tabular}

Hasil pemeriksaan penunjang pada pasien PJR (Tabel 3.) didapatkan 19 pasien (35,19\%) yang mengalami LVH, 15 pasien (27,78\%) mengalami fibrilasi atrium (AF), dan 50 pasien (92,59\%) mengalami kardiomegali.

Tabel 3. Distribusi pasien PJR berdasarkan pemeriksaan penunjang

\begin{tabular}{ccc}
\hline Pemeriksaan EKG & $\mathbf{n}$ & $\%$ \\
\hline Tidak terdapat hipertrofi jantung & 7 & 12,96 \\
LVH & 19 & 35,19 \\
RVH & 12 & 22,22 \\
BVH & 16 & 29,63 \\
Jumlah & 54 & 100 \\
\hline
\end{tabular}

Pemeriksaan EKG

\begin{tabular}{ccc}
\hline Tidak terdapat AF & 39 & 72,22 \\
$\mathrm{AF}$ & 15 & 27,78 \\
Jumlah & 54 & 100 \\
\hline
\end{tabular}

\begin{tabular}{lcc} 
Pemeriksaan Foto Toraks & \\
\hline Tidak terdapat kardiomegali & 4 & 7,41 \\
Kardiomegali & 50 & 92,59 \\
Jumlah & 54 & 100
\end{tabular}

Keterangan LVH = Left Ventricle Hypertrophy; RVH = Right Ventricle Hypertrophy; BVH = Biventricular Hypertrophy, $\mathrm{AF}=$ Atrial Fibrillation 
Kelainan katup dan derajat kelainan katup menurut hasil pemeriksaan ekokardiografi (Tabel 4) didapatkan kelainan katup dan derajat kelainan katup yang terbanyak adalah regurgitasi mitral sebanyak 38 sampel $(30,40 \%)$ dan kelainan katup severe yang diderita 46 sampel $(36,80 \%)$.

Fraksi ejeksi dari 54 sampel hanya 37 pasien yang memiliki data mengenai fraksi ejeksi. Berdasarkan fraksi ejeksi, didapatkan 27 sampel (72,97\%) dengan nilai normal dan 10 sampel $(27,03 \%)$ dengan nilai fraksi ejeksi rendah. Keseluruhan pasien ditatalaksana dengan medikamentosa dan tidak ada pasien yang ditatalaksana dengan pembedahan.

Lama rawatan rata-rata pasien PJR adalah 9,61 hari (10 hari) dengan standard Deviasi 6,73. Lama rawatan pasien bervariasi dari 0 hari hingga 36 hari. Keadaan pasien PJR sewaktu pulang sebagian besar dengan dipulangkan, yaitu sebanyak 34 orang (62,96\%) dan yang terendah adalah dirujuk yaitu 4 orang.

Tabel 4. Distribusi pasien PJR berdasarkan kelainan katup dan derajat kelainan katup menurut hasil ekokardiografi

\begin{tabular}{|c|c|c|c|c|c|c|c|c|c|c|c|c|}
\hline \multirow{3}{*}{ KelainanKatup } & \multirow{3}{*}{$\mathbf{n}$} & \multirow{3}{*}{$\%$} & \multicolumn{10}{|c|}{ Derajat Kelainan Katup } \\
\hline & & & \multicolumn{2}{|c|}{ Mild } & \multicolumn{2}{|c|}{$\begin{array}{c}\text { Mild- } \\
\text { Moderate }\end{array}$} & \multicolumn{2}{|c|}{ Moderate } & \multicolumn{2}{|c|}{$\begin{array}{c}\text { Moderate- } \\
\text { Severe }\end{array}$} & \multicolumn{2}{|c|}{ Severe } \\
\hline & & & $\mathbf{n}$ & $\%$ & $\mathbf{N}$ & $\%$ & $\mathbf{n}$ & $\%$ & $\mathbf{n}$ & $\%$ & $\mathbf{n}$ & $\%$ \\
\hline MR & 38 & 30,40 & 7 & 5,60 & 2 & 1,60 & 5 & 4 & 6 & 4,80 & 18 & 14,40 \\
\hline MS & 22 & 17,60 & 1 & 0,80 & 1 & 0,80 & 6 & 5 & 5 & 4 & 9 & 7,20 \\
\hline AR & 34 & 27,20 & 7 & 5,60 & 5 & 4 & 10 & 8 & 3 & 2,40 & 9 & 7,20 \\
\hline AS & 5 & 4 & 4 & 3,20 & 0 & 0 & 1 & 0,80 & 0 & 0 & 0 & 0 \\
\hline TR & 24 & 19,20 & 5 & 4 & 0 & 0 & 6 & 5 & 3 & 2,40 & 10 & 8 \\
\hline TS & 0 & 0 & 0 & 0 & 0 & 0 & 0 & 0 & 0 & 0 & 0 & 0 \\
\hline PR & 2 & 1,60 & 1 & 0,80 & 1 & 0,80 & 0 & 0 & 0 & 0 & 0 & 0 \\
\hline PS & 0 & 0 & 0 & 0 & 0 & 0 & 0 & 0 & 0 & 0 & 0 & 0 \\
\hline Jumlah & 125 & 100 & 25 & 20 & 9 & 7,20 & 28 & 22,40 & 17 & 13,60 & 46 & 36,80 \\
\hline
\end{tabular}

Keterangan : MR = Mitral Regurgitation; MS = Mitral Stenosis; $\mathrm{AR}=$ Aorta Regurgitation; $\mathrm{AS}=$ Aorta Stenosis; TR = Tricuspid Regurgitation; TS = Tricuspid Stenosis; PR = Pulmonal Regurgitation; PS = Pulmonal Stenosis

\section{PEMBAHASAN}

Penyakit jantung rematik merupakan penyakit jantung sebagai akibat adanya gejala sisa (sekuele) dari DR. ${ }^{4}$ Demam rematik terutama terjadi pada anak usia 514 tahun dan dapat terjadi kekambuhan pada usia dekade keempat. Puncak kejadian PJR adalah pada dekade ketiga dan keempat. ${ }^{5}$ Pasien PJR yang termasuk dalam penelitian ini terdiri atas 54 sampel dengan kelompok usia yang tertinggi terdapat pada usia 11- 20 tahun, yaitu sebanyak 27 sampel (50\%) dan yang terendah pada kelompok umur usia lanjut ( $\geq 60$ tahun) sebanyak 1 sampel (1,85\%). Penelitian ini sesuai dengan penelitian yang dilakukan Parnaby dan Carapertis pada penduduk asli Australia di Australia bagian utara dan tengah pada tahun 2010, dimana angka kejadian PJR yang tinggi adalah pada rentang usia 15 hingga 45 tahun, dengan puncak kejadian PJR pada usia 35-44 tahun, yaitu 31,9 per 1000 penduduk. ${ }^{6}$

Berdasarkan penelitian pada penduduk pribumi di wilayah Australia utara yang menderita PJR pada tahun
2010 didapatkan angka kejadian PJR lebih tinggi pada perempuan dibandingkan laki-laki dengan perbandingan 1,9:1. ${ }^{6}$ Pada penelitian ini, sebagian besar pasien PJR berjenis kelamin perempuan yaitu sebanyak 31 orang $(57,41 \%)$ dan pasien laki-laki sebanyak 23 orang (42,59\%). Hasil penelitian ini sesuai dengan penelitian yang dilakukan pada anak usia sekolah berkulit hitam di Soweto Johannesburg pada tahun1972, dimana kejadian PJR pada perempuan lebih tinggi dibandingkan pada laki-laki dengan perbandingan 1,6:1.7 Hasil ini tidak jauh berbeda dengan penelitian yang dilakukan oleh Melani di Medan pada tahun 2009, didapatkan proporsi pasien pasien yang berjenis kelamin perempuan $54,3 \%$ dan laki-laki sebanyak $45,7 \% .^{8}$ Namun, berdasarkan penelitian terkini di negara berkembang, memperlihatkan hubungan yang tidak konsisten antara jenis kelamin dan PJR. Beberapa penelitian dari Asia Selatan, Timur Tengah, dan Afrika Utara memperlihatkan PJR lebih sering mengenai perempuan. ${ }^{9}$ 
Tingkat pendidikan yang rendah berhubungan dengan faktor risiko terjadinya DR dan PJR dimana berkaitan dengan kesadaran akan penyakit, pencegahan, dan pengobatan. ${ }^{10}$ Berdasarkan pendidikan, didapatkan distribusi pasien PJR yang tertinggi terdapat pada pasien dengan tingkat pendidikan SD/sederajat dan SLTP/sederajat yaitu masing-masing sebanyak 14 orang $(25,93 \%)$, dan yang terendah adalah berpendidikan Akademi/PT sebanyak 2 orang (3,70\%). Hasil penelitian ini sejalan dengan penelitian yang dilakukan oleh Melani di RSUP H. Adam Malik Medan pada tahun 2009 yaitu proporsi penderita PJR yang tertinggi adalah yang berpendidikan SD/sederajat dan SLTP/sederajat yaitu 33,3\% dan yang terendah adalah berpendidikan Akademi/PT sebesar 1,9\%. ${ }^{8}$

Pekerjaan sebagian besar pekerjaan pasien PJR merupakan pelajar/mahasiswa, yaitu sebanyak 29 orang $(53,70 \%)$ dan yang paling sedikit bekerja sebagai petani/nelayan yaitu sebanyak 2 orang (3,70\%). Pasien PJR lebih banyak merupakan pelajar/mahasiswa, dimana hal ini berhubungan dengan distribusi pasien PJR yang mayoritas pada usia muda dan produktif. Hasil penelitian ini didukung dengan laporan angka kejadian PJR yang tinggi pada anak sekolah di Samoa pada tahun 1999, dimana ditemukan 77,8 kasus per 1000 anak sekolah. ${ }^{1}$

Daerah asal disimpulkan bahwa sebagian besar pasien PJR berasal dari daerah rural yaitu sebesar $70,37 \%$. Hal ini berkaitan dengan faktor risiko terjadinya DR dan PJR yaitu faktor lingkungan yang buruk. Dimana hal ini berhubungan dengan tingginya angka penyebaran dari bakteri SGA sehingga meningkatkan angka kejadian DR dan PJR. ${ }^{1}$ Penelitian ini didukung oleh penelitian yang dilakukan Parnaby dan Carapertis pada penduduk asli Australia di Australia bagian utara dan tengah pada tahun 2010, didapatkan PJR merupakan masalah utama pada seluruh penduduk asli yang tinggal didaerah rural (pedesaan) dan daerah terpencil. ${ }^{6}$ Berdasarkan penelitian yang dilakukan di Pakistan pada tahun 2004, ditemukan 500.000 pasien dengan PJR dari 88 juta penduduk Pakistan yang tinggal didaerah rural (pedesaan). ${ }^{9}$

Keluhan utama yang paling banyak dikeluhkan pasien PJR adalah sesak napas yaitu sebesar 34 pasien (62,96\%). Pasien dengan penyakit kardiopulmonal secara umum mengalami gangguan pernapasan, yang dikeluhkan sebagai sesak napas. ${ }^{11}$ Sebagian besar pasien dengan disfungsi ventrikel kiri mengeluhkan sesak napas walaupun belum terjadi gagal jantung. Kebanyakan pasien dengan gangguan ventrikel kiri memiliki respon ventilasi yang berlebihan terhadap latihan. $^{12}$ Secara umum pasien PJR mengalami gangguang fungsi jantung, dimana hal ini diakibatkan oleh kelainan pada katup jantung dan akibat kompensasi jantung sehingga terjadi sesak napas. Hasil penelitian ini sejalan dengan penelitian yang dilakukan oleh Melani di RSUP H. Adam Malik Medan tahun 2009 dimana sesak napas dikeluhkan oleh $89,5 \%$ sampel. $^{8}$

Hasil pemeriksaan EKG didapatkan 19 pasien (35,19\%) mengalami hipertrofi ventrikel kiri $(\mathrm{LVH}), 16$ pasien mengalami pembesaran kedua ventrikel, 12 pasien mengalami pembesaran ventrikel kanan. Sebagian besar pasien tidak mengalami fibrilasi atrium $(72,22 \%)$ dan hanya 15 pasien $(27,78 \%)$ yang mengalami AF. Pemeriksaan EKG pada pasien PJR tidak memberikan gambaran yang spesifik, hanya dapat menilai adanya pembesaran atrium atau ventrikel kiri. ${ }^{10}$ Ventrikel kiri melebar untuk memberi tempat pada darah regurgitan dan darah dari vena pulmonalis. ${ }^{13}$ Pada pasien PJR yang disertai AF risiko terjadinya stroke meningkat menjadi 17 kali lipat dibandingkan pada pasien AF tanpa PJR. ${ }^{14}$

Berdasarkan hasil pemeriksaan foto toraks didapatkan sebagian besar pasien PJR mengalami kardiomegali yaitu sebesar $92,59 \%$ dan hanya sebagian kecil saja yang tidak mengalami kardiomegali $(7,41 \%)$. Gambaran foto toraks pasien MR kronis dapat ditemukan pembesaran ventrikel kiri dan tanda-tanda kongesti paru. Begitu juga dengan MS dapat memperlihatkan pembesaran atrium dan redistribusi aliran darah pulmonalis ke paru bagian atas. Pada AR dapat memperlihatkan pembesaran ventrikel kiri dan pelebaran aorta asendens. Gambaran foto toraks pada stenosis aorta (AS) biasanya memperlihatkan ukuran jantung normal, kecuali jika disertai dengan regurgitasi mitral. ${ }^{10}$

Berdasarkan kelainan katup pada sampel didapatkan MR merupakan kelainan katup yang paling sering terjadi, yaitu sebesar $30,40 \%$ dan tidak terdapat kasus stenosis trikuspid (TS) dan stenosis pulmonal (PS). Secara teoritis, dikatakan bahwa lesi katup mitral merupakan yang paling sering terjadi pada PJR, yaitu 
kira-kira tiga perempat dari keseluruhan pasien PJR. Stenosis aorta tanpa keterlibatan katup mitral merupakan kasus yang sangat jarang terjadi. Keterlibatan katup trikuspid dan pulmonal hampir tidak pernah terjadi. ${ }^{15}$ Berdasarkan penelitian pada suku Aborigin, 40 pasien PJR mengalami MR dan $90 \%$ pasien anak usia dibawah 10 tahun mengalami MR. Regurgitasi mitral adalah kelainan katup yang sering ditemukan pada pasien usia muda, dimana belum terjadi jaringan parut pada katup dan stenosis katup. ${ }^{10}$ Hasil penelitian ini didukung oleh penelitian yang dilakukan di Soweto Johannesburg pada tahun 1975, dimana MR ditemukan pada $95 \%$ sampel. $^{7}$

Derajat kelainan katup yang paling banyak ditemukan adalah severe yaitu sebanyak 36,80\% sampel dan yang paling sedikit adalah mild-moderate sebanyak $7,20 \%$ sampel. ${ }^{10}$ Derajat kelainan katup berkaitan dengan tatalaksana yang harus diberikan pada pasien. Pasien dengan PJR sedang (moderate) hingga berat (severe) rentan terhadap DR berulang sehingga membutuhkan profilaksis sekunder dengan durasi yang lebih lama. ${ }^{10}$ Setiap pasien yang didiagnosa menderita DR minimum mendapat profilaksis sekunder selama 10 tahun. ${ }^{1,10}$ Setelah fase awal penggunaan profilaksis ini terlampaui, maka akan dilanjutkan dengan profilaksis sekunder sesuai dengan derajat PJR. Jika tidak ditemukan PJR atau PJR ringan (mild) profilaksis dihentikan, jika PJR sedang (moderate) profilaksis sekunder dilanjutkan hingga berusia 35 tahun. Namun, jika PJR berat (severe), diberikan profilaksis sekunder hingga usia 40 tahun atau lebih. ${ }^{10}$ Tingginya angka kejadian kelainan katup dengan derajat severe membuktikan bahwa dibutuhkannya penatalaksanaan yang lebih dini dan komprehensif terhadap pasien PJR untuk mencegah terjadinya perburukan keadaan pasien dan meningkatkan kualitas hidup pasien. ${ }^{1}$

Derajat kelainan katup yang terbanyak adalah regurgitasi mitral (MR) severe yaitu sebesar 14,40\%. Pasien PJR dengan MR severe membutuhkan penatalaksanaan dengan intervensi bedah. ${ }^{10}$

Dari 54 sampel, hanya 37 sampel yang memiliki data mengenai fraksi ejeksi. Hal ini disebabkan beberapa pasien merupakan pasien kontrol lama dan sudah mendapatkan pemeriksaan ekokardiografi berulang, sehingga fraksi ejeksi yang sudah pernah dinilai sebelumnya tidak dituliskan lagi dalam data pasien. Sebanyak 37 sampel yang memiliki data mengenai fraksi ejeksi, sebagian besar sampel (72,97\%) masih menunjukkan fraksi ejeksi dalam batas normal, dan $27,03 \%$ sampel dengan nilai fraksi ejeksi rendah. Fungsi sistolik ventrikel kiri dapat dinilai berdasarkan fraksi ejeksi, fraksi pemendekan, dan systolic time intervals. Fraksi ejeksi berhubungan dengan perubahan volume ventrikel kiri terhadap kontraksi jantung. ${ }^{15}$

Secara keseluruhan tatalaksana terhadap pasien PJR dilakukan dengan medikamentosa. Setiap pasien yang didiagnosa sebagai DR/PJR membutuhkan penanganan dengan profilaksis sekunder, hal ini untuk mencegah serangan ulang dari DR akut. Sehingga, pasien PJR membutuhkan profilaksis sekunder jangka panjang. ${ }^{1,10}$ Beberapa pasien PJR severe (berat) merupakan indikasi penatalaksanaan bedah, namun dikarenakan kurang lengkapnya peralatan dan tidak adanya tim khusus untuk intervensi bedah menjadi faktor penyebab sulitnya dilakukan penatalaksanaan bedah di RSUP Dr. M. Djamil Padang.

Lama rawatan rata-rata pasien PJR adalah 9,61 (10) hari dan standar deviasi (SD) 6,73, artinya lama rawatan pasien PJR bervariasi dari lama rawatan minimum adalah 0 hari hingga lama rawatan maksimum adalah 36 hari. Rawatan rumah sakit diperlukan untuk memonitor keadaan pasien dan untuk penanganan yang cepat. Selain itu, penderita PJR diharuskan tirah baring di rumah sakit karena pada pasien PJR dilakukan penatalaksanaan medis yaitu penegakan diagnosis meliputi pemeriksaan laboratorium seperti ASTO, LED, CRP dan juga untuk kemoprofilaksis sekunder untuk mencegah serangan ulang DR. ${ }^{1}$

Sebagian besar pasien dipulangkan dengan perbaikan yaitu sebanyak 34 pasien (62,96\%), pulang paksa 11 pasien (20,37\%), dirujuk 4 pasien (7,41\%), dan hanya 5 pasien $(9,26 \%)$ yang meninggal dunia. Sebagian besar pasien PJR dipulangkan karena keadaan pasien yang sudah membaik dengan keluhan yang berkurang dan hasil pemeriksaan yang menunjukkan perbaikan. Namun, pasien PJR yang dipulangkan diberikan jadwal kontrol untuk kembali memeriksaan keadaan penyakitnya dan untuk jadwal pemberian profilaksis sekunder. ${ }^{1}$ Hasil penelitian ini sesuai dengan penelitian yang dilakukan oleh Melani di 
RSUP H. Adam Malik Medan pada tahun 2009, dimana $78,1 \%$ keadaan pasien sewaktu pulang adalah pulang berobat jalan. ${ }^{8}$

\section{KESIMPULAN}

Sosiodemografi distribusi pasien PJR terbanyak pada kelompok umur 15-59 tahun, jenis kelamin perempuan, pendidikan SD/sederajat dan SLTP/sederajat, pekerjaan pelajar/mahasiswa, dan berasal dari daerah rural (pedesaan).

Keluhan utama distribusi pasien PJR terbanyak adalah keluhan sesak napas. Berdasarkan hasil pemeriksaan elektrokardiografi distribusi pasien PJR terbanyak adalah hipertrofi ventrikel kiri. Berdasarkan hasil pemeriksaan foto toraks distribusi pasien PJR terbanyak adalah terdapatnya pembesaran jantung (kardio-megali).

Hasil pemeriksaan ekokardiografi distribusi pasien PJR terbanyak adalah kelainan katup regurgitasi mitral, derajat kelainan katup severe (berat), kelainan katup berdasarkan derajat kelainan katup yang terbanyak adalah regurgitasi mitral severe, dan fraksi ejeksi masih dalam batas normal.

\section{UCAPAN TERIMA KASIH}

Terima kasih kepada Direktur RSUP Dr. M Djamil beserta Staf yang sudah membantu dalam penelitian ini.

\section{DAFTAR PUSTAKA}

1. WHO. Rheumatic fever and rheumatic heart disease: report of a WHO Expert Consultation, Geneva, 29 Oct-1 Nov 2001: Geneva; WHO Technical report series No.923; 2004; p1-65.

2. Soeroso S. Tinjauan prevalensi demam rematik dan penyakit jantung rematik pada anak di Indonesia. Dalam: Sastrosubroto $H$, editor (penyunting). Semarang: Naskah Lengkap Simposium dan Seminar Kardiologi Anak; 1986. hlm. 1-11.

3. Leman S. Demam rematik dan penyakit jantung rematik. Dalam: Sudoyo AW, Setiyohadi B, Alwi I, Simadibrata $M$, Setiati $A$, editor (penyunting). Buku Ajar IImu Penyakit Dalam: Jakarta; Internal Publishing; 2009. hlm.1662-8.

4. Siregar AA. Demam rematik dan penyakit jantung rematik permasalahan Indonesia. Dalam: Pidato pengukuhan jabatan guru besar tetap pada fakultas kedokteran diucapkan dihadapan rapat terbuka Universitas Sumatera Utara. 2008 (diunduh 1 Juni 2013). Tersedia dari: URL: HYPERLINK http://repository.usu.ac.id/.

5. Carapertis J, Brown A, Maguire G, Walsh W. Diagnosis and management of acute rheumatic fever and rheumatic heart disease in Australia; National Heart Foundation of Australia; 2006; 50-59.

6. Parnaby MG, Carapertis JR. Rheumatic fever in indigenous Australian children. Journal of Pediatrics and Child Health. 2010;46(10):527-33.

7. McLaren MJ, Hawkins DM, Koornhof HJ, Bloom KR, Bramwell-Jones DM, Cohen E, Gale GE, et al. Epidemiology of rheumatic heart disease in black schoolchildren of Soweto, Johannesburg. British Medical Journal. 1975:474-8.

8. Melani TA. Karakteristik penderita penyakit jantung rematik (PJR) yang dirawat inap di RSUP H. Adam Malik Medan tahun 2004-2008 (skripsi). Medan: Universitas Sumatera Utara; 2009.

9. Rizvi SF, Khan MA, Kundi A, Marsh DR, Samad A, Pasha O. Status of rheumatic heart disease in rural pakistan. Heart. 2004;90;394-9.

10. Carapertis J, Brown A, Maguire G, Walsh W, Noonan $S$, Thompson D, et al. The Australian guideline for prevention, diagnosis and management of acute rheumatic fever and rheumatic heart disease. Edisi ke-2. National Heart Foundation of Australia and the Cardiac Society of Australia and New Zealand. Menzies School of Heart Research; 2012; 30-98.

11. Manning HL, Schwartzstein RM. Pathophysiology of dyspnea. Waltham : Massachusetts Medical Society. 1995;333(No. 23);1547-53.

12. Manning $\mathrm{HL}$, Mahler DA. Patho-physiology of dyspnea. Lebanon : Monaldi Arch Chest Dis.2001;56;325-30.

13. Sastroasmoro S, Madiyono B. Buku ajar kardiologi anak. Jakarta: Binarupa Akasara;1994; 279-343.

14. Rosenthal L, McManus D. Atrial fibrillation treatment \& management.. (diunduh 2 Juni 2013). Tersedia dari URL: HYPERLINK http://emedicine.medscape. com/article/151066-treatment

15. Park MK. Pediatric cardiology for practicioner. Edisi ke-5. Philadelphia: Mosby Elsevier;2008. 